\title{
Spinal epidural abscess - a rare complication of Crohn's disease: case report
}

\author{
Karolina Poredská', Vladimír Zbořil', Lucie Prokopová', Lenka Kučerová', Milan Dastych', \\ Svatopluk Richter', Petra Praksová3 ${ }^{3}$ Jiří Dolina', Lumír Kunovský1,4 \\ 'Department of Gastroenterology and Internal Medicine, Faculty of Medicine, Masaryk University, and University Hospital Brno, \\ Czech Republic \\ 2Department of Radiology and Nuclear Medicine, Faculty of Medicine, Masaryk University, and University Hospital Brno, \\ Czech Republic \\ ${ }^{3}$ Department of Neurology, Faculty of Medicine, Masaryk University, and University Hospital Brno, Czech Republic \\ ${ }^{4}$ Department of Surgery, Faculty of Medicine, Masaryk University, and University Hospital Brno, Czech Republic
}

\section{Summary}

Spinal epidural abscess (SEA) is a rare disease that occurs mainly in immunocompromised patients after spinal surgery or spinal trauma and can lead to a severe neurological deficit or even death if diagnosed too late. However, cases of SEA have also been reported in patients with fistulising Crohn's disease (CD). We present a case of a young patient with CD and a history of relapsing perianal disease followed by a complication of SEA in the thoracic spine. In close cooperation with the orthopedists and the neurologists, the gastroenterologists have successfully treated the SEA in this patient, allowing her to return back to biological treatment for CD.

Key words: biological treatment - Crohn's disease - perianal fistulas - spinal epidural abscess

\section{Epidurálni absces páteře - raritní komplikace Crohnovy choroby:}

\section{kazuistika}

\section{Souhrn}

Epidurální absces páteře je raritní onemocnění, které se objevuje především u imunokompromitovaných pacientů po operacích nebo úrazech páteře a pokud je diagnostikováno přiliš pozdě, může vést k těžkému neurologickému deficitu nebo dokonce smrti. V literatuře jsou ovšem popsány i případy epidurálního abscesu páteře u pacientů s fistulující formou Crohnovy choroby. Představujeme kazuistiku mladé pacientky s Crohnovou chorobou a recidivujícím perianálním postižením, které bylo komplikováno vznikem epidurálního abscesu v oblasti hrudní páteře. I díky úzké spolupráci s ortopedy a neurology se podařilo gastroenterologům pacientku úspěšně léčit. Následně tak pacientce mohla být navrácena biologická léčba potřebná pro komplikovaný průběh Crohnovy choroby.

Klíčová slova: biologická léčba - Crohnova choroba - epidurální absces páteře - perianální píštěl

\section{Introduction}

Spinal epidural abscess (SEA) is a rare disease with incidence of $2-5 / 10000$ hospitalisations, which is however growing probably due to aging of the population, increases in the numbers of immunocompromised patients and spinal surgeries and improvements in the quality of radiological diagnostics [1,2]. Unfortunately, the mortality of SEA is up to $15 \%$ if diagnosed too late. The location of SEA is mainly the lumbar spine and the etiology is mostly a hematogenous spread from a distant septic focus (such as skin furuncles, dental or tonsillar abscess, pneumonia, renal or psoas abscess) but it can also be direct after a trauma or even iatrogenic
[1-3]. Typically, the causative organism cultivated from SEA is Staphylococcus aureus. The main presenting symptoms are back pain, fever and a variable degree of neurological deficit $[2,3]$. SEA is rare in patients with inflammatory bowel disease (IBD), with only a few cases reported - mostly in patients with fistulising Crohn's disease (CD); however, a case of SEA has also been reported in a patient with ulcerative colitis after proctocolectomy with ileal pouche-anal anastomosis [4].

\section{Case report}

A 24-year-old woman was followed up at our department for $C D$ diagnosed at the age of 14 and located in 
the colon and perianal region. She had been treated with adalimumab biologics already for 2 years. This therapy was discontinued in the third trimester of her first gravidity. During the pregnancy she was treated for relapsing perianal abscess with a need of drainage, where the last drainage was performed 14 days before the delivery. Eventually, she delivered a healthy child by a Caesarean section in general anesthesia. The woman's family had a history of Bechterev disease. Three months after the delivery, she was referred to our department by her general practitioner for lower back pain and fever lasting for 3 weeks.

On examination she was asthenic, slightly hypotensive, tachycardic (with the heart rate of 120 beats per minute), with no apparent neurological deficit, her abdomen was not tender, with only mildly positive tappotement bilaterally. Rectal examination showed scars after healed abscesses but no signs of active disease.

Within the wide differential diagnosis, the following investigations were performed. In terms of laboratory findings, the C-reactive protein ( $115 \mathrm{mg} / \mathrm{l})$ and border microcytic anaemia were identified; on the other hand, the urinary and stool samples did not show any pathology, and neither did the hemoculters, nor the X-ray and ultrasound of the abdomen, nor the X-ray of the lungs and thoracic and lumbar spine, nor the gynecological examination. Additionally, the neurologist concluded that there were slightly positive upper meningeal symptoms and therefore recommended an acute magnetic resonance imaging (MRI) of the spine to exclude an epidural abscess or other source of infection. The MRI (fig. 1a, fig. 1b, fig. 2) showed epidural abscess formation in the thoracic spine compressing the dural sac but not the spinal cord.

Given the mild neurological deterioration and quite favourable MRI findings, the patient was treated conservatively with antibiotics (oxacillin and cefotaxim) for two weeks, and subsequently with co-trimoxazol and rifampicin for two months. She was allowed to move with a spinal corset. After three months, she was completely asymptomatic, finished the antibiotic treatment and the control MRI of the spine (Fig. 3,4) showed regression of the abscess. Considering the favorable results, the patient could return back to the biological treatment needed for CD.

\section{Discussion}

SEA is a rare condition that can be fatal if underdiagnosed [1-3]. The most important factor in the therapeutic decision is the level and progression of neurological deterioration that can vary from simple back pain to signs of meningism, motor, sensor or sphincter dysfunction and even paraparesis [5]. The final diagnose is made by MRI. The findings then serve as a basis for therapy, which can be either conservative or surgical. As to the possibility of conservative therapy, it is possible to use antibiotics with a good penetration to the spine in neurologically stabilized patients. In contrast, in patients whose neurological deficit is worsening quickly, it is necessary to perform surgical decompression of the spine, sometimes even an urgent one. The most common procedure performed is a dorsal approach laminectomy [5].

Only a few cases of SEA in patients with CD have been reported, in which the etiology of SEA was mostly wide-
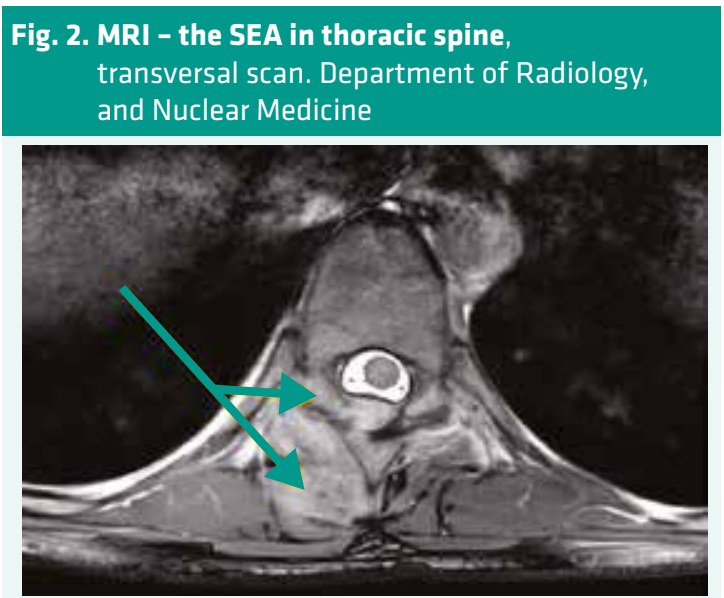

Fig. 1. MRI - the SEA in thoracic spine, sagital scan. Department of Radiology, and Nuclear Medicine

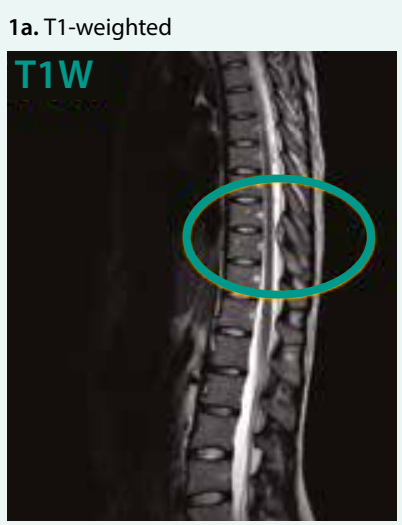

1b. T2-weighted

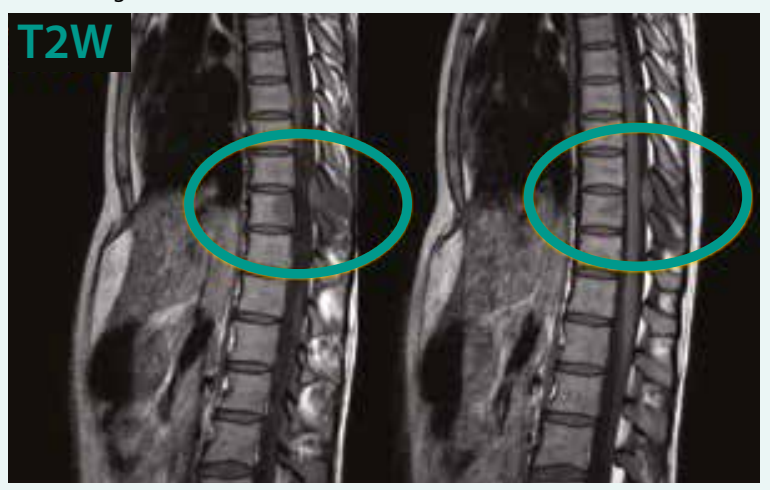


Fig. 3. Control MRI after 3 months showing regression of SEA, sagital scan. Department of Radiology, and Nuclear Medicine

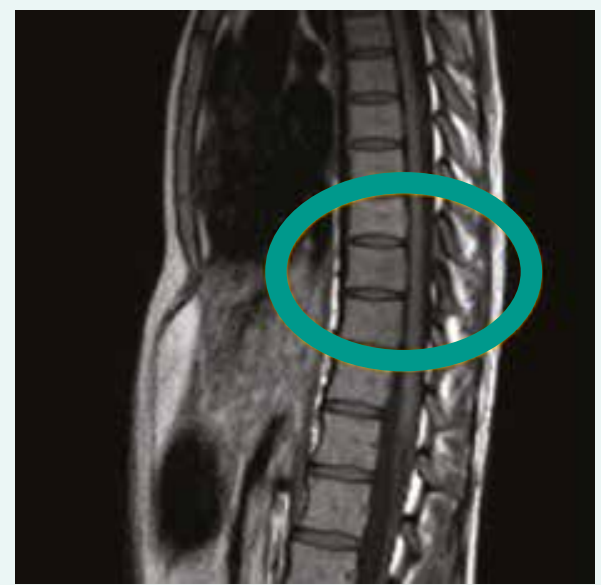

Fig. 4. Control MRI after 3 months showing regression of SEA, transversal scan. Department of Radiology, and Nuclear Medicine

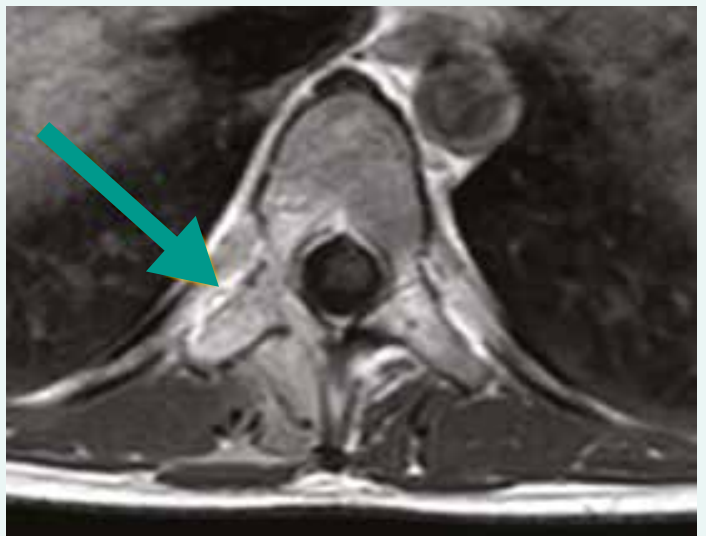

spread from the perianal fistulas or abscess [4]. Fistulas can appear in patients with CD in 17-50 \% of cases, with a recurrence in $1 / 3$ of patients, moreover the cumulative incidence of developing a fistula in $\mathrm{CD}$ patients is approximately $20 \%$ after 1 year and $50 \%$ after 20 years [6-8]. Our patient was treated several times for perianal abscess during her pregnancy; however, when she was admitted for SEA, the perianal region was already healed (according to the MRI findings of the pelvis). The patients with CD and SEA reported in the literature were for their CD mostly treated with steroids or sulfasalazine whereas our patient was receiving with biological treatment, namely adalimumab, which can have an adverse effect of opportunistic infection [9-11]. A majority of patients with CD complicated by SEA had to be treated surgically (laminectomy); nonetheless, our patient was successfully treated conservatively with antibiotics $[9,11]$. Furthermore, in some surgically treated patients, early recurrence of SEA has been reported. Fortunately, this has not happened in our case and one year later, the patient shows no signs of recurrence of SEA. Moreover, she is able to continue with her biological treatment for CD.

\section{Conclusion}

We present a rare case of SEA of the thoracic spine in a 24-year-old woman as a complication of perianal CD that was successfully treated conservatively with antibiotics.

Supported by Ministry of Health, Czech Republic-conceptual development of research organization (FNBr, 65269705).

\section{References}

1. Vakili M, Crum-Clanflone N. Spinal Epidural Abscess: A Series of 101 Cases. Am J Med 2017; 130(12): 1458-1463. Dostupné z DOI: <http://dx.doi.org/10.1016/j.amjmed.2017.07.017>.

2. Ju MW, Choi SW, Kwon HJ et al. Treatment of Spinal Epidural Abscess and Predisposing Factors of Motor Weakness: Experience with 48 Patients. Korean J Spine 2015; 12(3): 124-129. Dostupné z DOI: <http://dx.doi.org/10.14245/kjs.2015.12.3.124>.

3. Reihaus $E$, Waldbaur $H$, Seeling W. Spinal epidural abscess: a meta-analysis of 915 patients. Neurosurg Rev 2000; 23(4): 175-204.

4. Gelfenbeyn M, Goodkin R, Kliot M. Sterile recurrent spinal epidural abscess in a patient with Crohn's disease: a case report. Surg Neurol 2006; 65(2): 178-184. Dostupné z DOI: <http://dx.doi.org/10.1016/j. surneu.2005.05.028>.

5. Suppiah S, Meng $Y$, Fehlings $M$ et al. How Best to Manage the Spinal Epidural Abscess? A Current Systematic Review. World Neurosurg 2016; 93: 20-28. Dostupné z DOI: Dostupné z DOI: <http://dx.doi. org/10.1016/j.wneu.2016.05.074>.

6. Schwartz D, Loftus EV, Tremaine $W$ et al. The natural history of fistulizing Crohn's disease in Olmsted County, Minnesota. Gastroenterology 2002; 122(4): 875-880. Dostupné z DOI: <http://dx.doi. org/10.1053/gast.2002.32362>.

7. Gesce K, Khanna R, Stoker J et al. Fistulizing Crohn's disease: Diagnosis and management. United European Gastroenterol J 2013; 1(3): 206 213. Dostupné z DOI: <http://dx.doi.org/10.1177/2050640613487194>.

8. Kunovsky L, Hemmelova B, Kala Z et al. Crohn disease and pregnancy: a case report of an acute abdomen. Int J Colorectal Dis 2016; 31(8): 1493-1494. Dostupné z DOI: <http://dx.doi.org/10.1007/ s00384-016-2554-1>.

9. Smith C, Kavar B. Extensive spinal epidural abscess as a complication of Crohn's disease. J Clin Neurosci 2010; 17(1): 144-146. Dostupné z DOI: <http://dx.doi.org/10.1016/j.jocn.2009.02.038>.

10. Kunovsky L, Kala Z, Marek F et al. The role of the NOD2/ CARD15 gene in surgical treatment prediction in patients with Crohn's disease. Int J Colorectal Dis 2019; 34(2): 347-351. Dostupné z DOI: <http://dx.doi.org/10.1007/s00384-018-3122-7>.

11. Brown CJ, Jaffer $\mathrm{H}$, Jafer $\mathrm{N}$ et al. Spinal epidural abscess a rare complication of inflammatory bowel disease. Can J Gastroenterol 2008; 22(2): 177-180. Dostupné z DOI: <http://dx.doi. org/10.1155/2008/893757>.

\section{Lumír Kunovský, M.D., PhD.}

\section{$\triangle$ lumir.kunovsky@gmail.com}

Department of Gastroenterology and Internal Medicine, Faculty of Medicine, Masaryk University, and University Hospital Brno, Czech Republic

\section{www.muni.cz}

Doručeno do redakce 3. 9. 2018

Prijato po recenzi 3. 12. 2018 